\title{
The parisite-(Ce) mineralization associated with the Fazenda Varela carbonatite (Correia Pinto, SC)
}

\section{Tamara Reginatto MANFREDI ${ }^{1}$, Artur C. BASTOS NETO ${ }^{1}$, Vitor P. PEREIRA ${ }^{1}$, Luc BARBANSON ${ }^{2}$ \& Cristine SCHUCK $^{1}$}

1. Instituto de Geociências, Universidade Federal do Rio Grande do Sul. Av. Bento Gonçalves, 9500, CEP 91540000, Porto Alegre, RS, Brazil. E-mail: tamararmanfredi@gmail.com, artur.bastos@ufrgs.br, vitor.pereira@ufrgs.br, cristine.schuck@gmail.com.

2. ISTO, Université d'Orléans/CNRS (UMR7327), Campus Géosciences. 1A rue de la Férollerie, 45071, Orléans, Cedex 2, France. E-mail: luc.barbanson@univ-orleans.fr.

\begin{abstract}
The Fazenda Varela carbonatite is part of the Lages alkaline complex (Late Cretaceous). The carbonatite occurs as abundant veins that cut the sandstones of the Rio Bonito Formation which are strongly brecciated and metasomatized. Petrography, geochemistry, X-ray diffraction, scanning electron microscopy and electron microprobe data allowed the identification and classification of REE fluorcarbonates. The carbonatite is composed essentially by ankerite and Fe-dolomite and was strongly affected for tardi and post magmatic events. The hydrothermal fluids percolated through fractures and grain boundaries and formed hydrothermal domains composed of barite, apatite, quartz, calcite, Fe-dolomite, and parisite-(Ce). In these domains, parisite-(Ce) occurs as well-developed fibrous to fibroradiated crystals. Parisite-(Ce) also occurs in hydrothermal veins that cut the metasomatized host rock. The parisite-(Ce) crystals are heterogeneous, occur in syntaxial growth with synchysite-(Ce), and have excess of Ca and REE and F depletions in relation to an ideal composition. The parasite-(Ce) mineralization formed from a fluid with low $\mathrm{F}$ activity that interacted with the rock and leached preferentially the LREE, which were likely transported as chlorine complexes.
\end{abstract}

Keywords: Fe-carbonatite, parisite, synchysite, REE.

Resumo - A mineralização de parisita-(CE) Associada ao carbonatito Fazenda Varela (Correia PinTo, SC). 0 carbonatito Fazenda Varela faz parte do complexo alcalino de Lages (SC), que pertence ao final do Cretáceo. 0 carbonatito ocorre na forma de abundantes veios que cortam arenitos da Formação Rio Bonito que foram fortemente brechados e metassomatizados. Os estudos petrográficos, geoquímicos, por difração de raios $\mathrm{X}$, por microssonda e por microscopia eletrônica de varredura permitiram identificar e classificar o principal fluorcarbonato portador de ETR da rocha. 0 carbonatito é composto essencialmente pelos carbonatos magmáticos ankerita e Fe-dolomita e foi fortemente afetado por eventos tardi a pós-magmáticos. Os fluidos percolaram através de fraturas e limites de grãos e formaram domínios hidrotermais compostos por barita, apatita, quartzo, calcita, ferrodolomita e parisita-(Ce). Nestes domínios, os cristais de parisita-(Ce) são fibrosos a fibrorradiais e bem desenvolvidos. Ela também existe em veios hidrotermais que cortam a encaixante metassomatizada. Os policristais de parisita-(Ce) são heterogêneos e têm crescimento sintaxial com a synchysita-(Ce). Sua composição média apresenta excesso de Ca e deficiência de ETR e de F em relação a uma composição ideal. A mineralização de parisita-(Ce) foi formada a partir de um fluido com baixa atividade de $\mathrm{F}$, que interagiu com a rocha lixiviando preferencialmente os ETRL que foram transportados provavelmente como complexos clorados.

Palavras-chaves: ferrocarbonatito, parisita, synchysita, ETR.

\section{Introduction}

Rare Earth Elements (REE) are lithophile, form deposits associated with many types of rocks and concentrate preferentially in carbonatites: 5 of the top 10 global REE deposits in exploitation are associated with carbonatites. Thus, carbonatites are the main target in the race to discover new REE reserves which has begun in 2009, when China, the largest producer in the world, announced that would only produce for its domestic market (Stone, 2009; Service, 2010).

The diversity of REE minerals is very large, but few minerals can be processed for the extraction of these elements at low costs. Mineralogy is the most critical problem in the evaluation of the economic viability of a deposit and fluorcarbonates are the most important 
REE ore minerals (Mariano \& Mariano, 2012). Fluorcarbonates are exploited in most known mines, such as Bayan Obo (China), where bastnäsite and synchysite are associated with carbonated rocks of unclear origin (Kynicky et al., 2012), and in many REE deposits outside of China, including Mountain Pass (USA), where magmatic bastnäsite is exploited from a carbonatite (Mariano \& Mariano, 2012). In most carbonatites, the REE are concentrated in other minerals. In some cases of exploitation, REE are the main product, such as Mount Weld (Australia), where monazite is exploited in lateritic crust (Lottermoser \& England, 1988; Lottermoser, 1990), and Kola (Russia), where REE are exploited from a mckelveyite carbohydrothermal deposit (Chakhmouradian \& Zaitev, 2012).

In Brazilian carbonatites, REE are (or will be) exploited as byproducts of phosphate, Ti or Nb ores, as in Catalão I (monazite, gorceixite and florencite), Araxá (burbankite, carbocernaite, ancylite, huanghoite and monazite), Serra Negra (rabdofane, florencite and crandallite) and Seis Lagos (Nb-rutile and florencite)
(Lapido-Loureiro, 1994; Cordeiro et al., 2011; Rocio et al., 2012). In Brazil, there are many other carbonatites with anomalous concentrations of REE, but in only two of them are the REE concentrated as fluorcarbonates. The first is Barra do Itapirapuã, where the hydrothermal REE mineralization of bastnäsite, parisite and synchysite was studied by Ruberti et al. (2008). The second is Fazenda Varela (Fig. 1), where only petrological studies were carried out (Scheibe, 1979; Scheibe \& Formoso, 1982; Menegotto \& Formoso, 1998) and the synchysite mineralization was interpreted as be magmatic.

This paper presents the first results of studies on the REE mineralization associated to the Fazenda Varela carbonatite. This research represents a rare opportunity to study mineralization in a carbonatite dome intruded in sedimentary rocks. The investigations revealed an original type of REE mineralization associated to carbonatite, represented by hydrothermal parisite-(Ce) without fluorite. The study of parisite-(Ce), in addition to the economic interests, represents a contribution to the mineralogical study of fluorcarbonates.

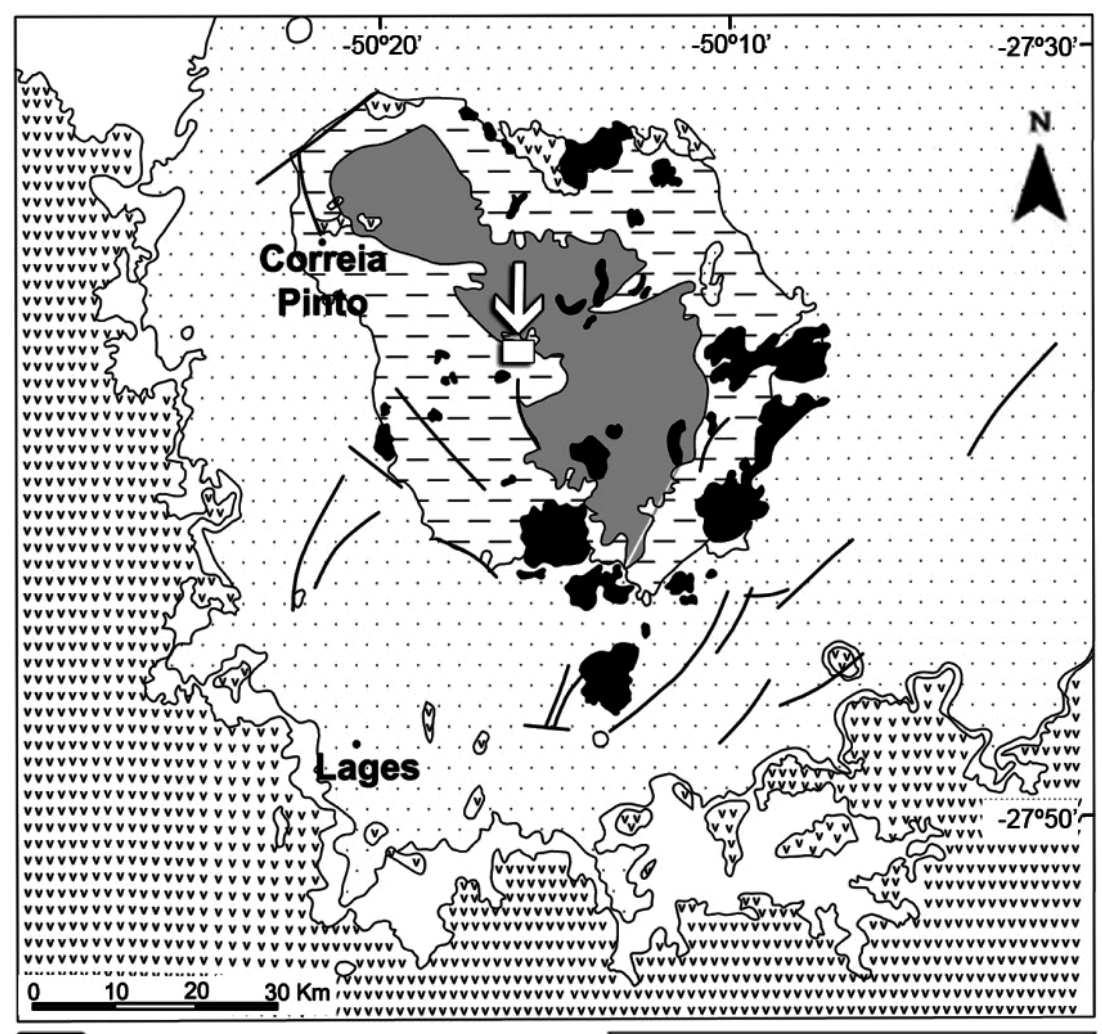

Lages Alkaline Complex

viv Serra Geral Formation

$\square$ Botucatu Formation

$\because$ Passo Dois Group

E Guatá Group

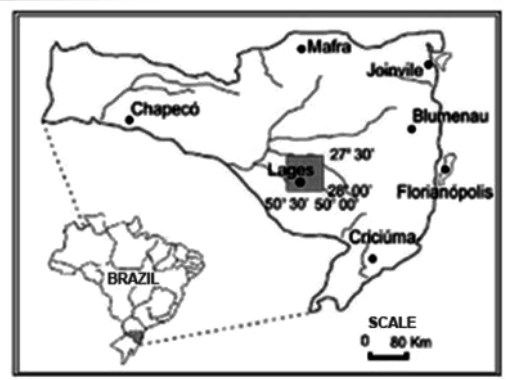

Itararé Group \ Fault

Figure 1. Geological map of the Lages alkaline district (modified from Scheibe, 1979 and Dani, 1998) and location of Fazenda Varela carbonatite, indicated by the arrow. 


\section{General concepts on REE Fluorcarbonates}

Parisite was first described in a Colombian emerald mine and occurs frequently in hydrothermal veins with calcite. In Brazil, this mineral was found in carbonatite (Ruberti et al., 2008) and as a secondary mineral in granites (Botelho \& Teixeira, 1995; Pereira et al., 2008).

Parisite belongs to the REE fluorcarbonates group also known as the bastnäsite series (Donnay \& Donnay, 1953). The group consists of four minerals: bastnäsite $\left(\mathrm{CeFCO}_{3}\right)$, synchysite $\left(\mathrm{CeFCO}_{3} \bullet \mathrm{CaCO}_{3}\right)$, parisite $\left(2 \mathrm{CeFCO}_{3} \bullet \mathrm{CaCO}_{3}\right)$, and röntgenite $\left(3 \mathrm{CeFCO}_{3} \bullet 2 \mathrm{CaCO}_{3}\right)$. Bastnäsite accounts for approximately $90 \%$ of the world's REE production; synchysite occurs subordinately and is associated with bastnäsite. In almost all the cases where bastnäsite is exploited, parisite and röntgenite are comparatively rare. The general mineral formula for the group is $n \mathrm{XYCO} 3 \cdot m \mathrm{CaCO} 3$, where $\mathrm{X}=$ LREE, $\mathrm{Y}=(\mathrm{F}, \mathrm{OH}): m=0$ (bastnäsite) or 1 (synchysite, parisite, röntgenite), $n=1$ (bastnäsite, synchysite), 2 (parisite) or 3 (röntgenite). Table 1 presents crystallographic and physical characteristics of these four minerals.

Table 1. Crystallographic data for the mineral serie bastnäsite-synchysite (Donnay \& Donnay, 1953; Wang et al., 1994).

\begin{tabular}{|c|c|c|c|c|c|c|c|c|c|}
\hline \multirow{2}{*}{ Mineral } & \multirow{2}{*}{ Crystal system } & \multicolumn{3}{|c|}{ Cell Dimensions $(\AA ̊)$} & \multirow{2}{*}{$\mathbf{Z}$} & \multirow{2}{*}{$\mathbf{V}\left(\AA^{3}\right)$} & \multirow[b]{2}{*}{$\rho$} & \multirow{2}{*}{$\begin{array}{c}\text { Point } \\
\text { Groups }\end{array}$} & \multirow{2}{*}{$\begin{array}{l}\text { Space } \\
\text { Group }\end{array}$} \\
\hline & & $a$ & $\mathrm{~b}$ & c & & & & & \\
\hline Bastnäsite & $\begin{array}{l}\text { hexagonal } \\
\text { bipyramidal }\end{array}$ & 7.16 & - & 9.79 & 6 & 434.65 & 5.02 & $\left({ }^{\overline{6}} \mathrm{~m} 2\right)$ & $\mathrm{P}^{\bar{\sigma}_{2 c}}$ \\
\hline Synchysite & $\begin{array}{l}\text { monoclinic } \\
\text { prismatic }\end{array}$ & 12.33 & 7.11 & 18.74 & 12 & $1,602.75$ & 3.97 & $(2 / \mathrm{m})$ & $\mathrm{C} 2 / \mathrm{c}$ \\
\hline Parisite & $\begin{array}{c}\text { trigonal } \\
\text { bipyramidal }\end{array}$ & 7.12 & - & 14.02 & 3 & 616.24 & 4.34 & $\overline{3}$ & R 3 \\
\hline Röntgenite & $\begin{array}{c}\text { trigonal } \\
\text { bipyramidal }\end{array}$ & 7.13 & - & 69.4 & 9 & $3,055.41$ & 4.19 & $\overline{3}$ & R 3 \\
\hline
\end{tabular}

As shown in table 1, only synchysite has the crystallographic $a$ parameter that is different from the other fluorcarbonates. Wang et al. (1994) show that synchysite displays monoclinic symmetry, whereas other species of the bastnäsite group show trigonal or hexagonal symmetry. The bastnäsite minerals group present two common features: (i) the structure can be broadly described as the stacking of three types of layers (CeF, $\mathrm{CO}_{3}$ and $\mathrm{Ca}$ ) along the $c$ axis; (ii) the $\mathrm{Ce} / \mathrm{F}$ ratios in all the phases are 1 , indicating that this feature is common in all minerals of the group. Thus, these minerals differ in the orientation of carbonate group within the carbonate layers, the order of staking of the different type of layers and the length of the crystallographic $c$ axis. According to Donnay \& Donnay (1953), in most cases, fluorcarbonates are polycrystals with syntaxial intergrowth of two species in contact along an irregular surface or along repeated parallel planes (0001). The $a$ axes of the two species may have the same or opposite directions. In the latter case, the two species are related to each other as two individual twins with a rotation of $60^{\circ}$ around the $c$ ternary axis. All pairs have been observed, except the bastnäsite-synchysite pair.

According to Caro (1973), parisite and röntgenite contain layers of bastnäsite and synchysite in varying proportions. Van Landuyt \& Amelinckx (1975) studied this group of minerals by transmission electron microscopy, revealing that the syntactic intergrowths can be described as mixtures of bastnäsite and synchysite. The authors considered bastnäsite-(Ce) and synchysite-(Ce) as two end-members and that parisite and röntgenite are ordered mixtures of bastnäsite (B) and synchysite $(\mathrm{S})$ in single layers stacked along the $c$ crystallographic axis direction. Parisite can be consid- ered a BS stacking and röntgenite a $\mathrm{BS}_{2}$ stacking. The structures of the members of the bastnäsite-synchysite series are shown in figure 2 .

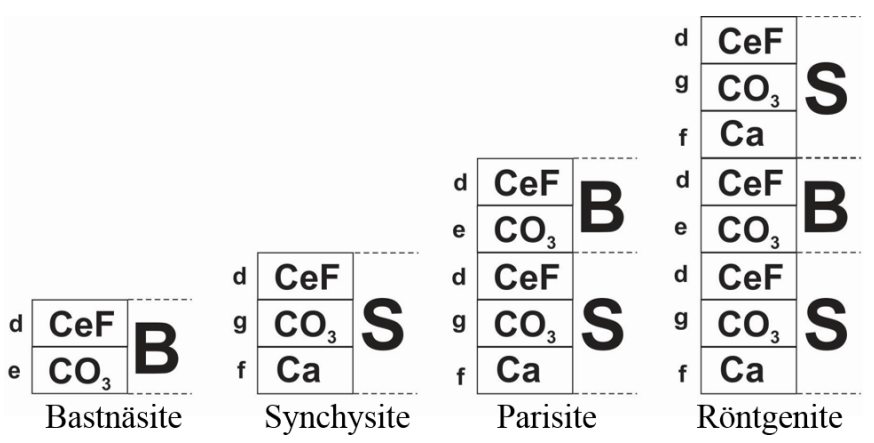

Figure 2. Crystal structure scheme of the bastnäsite mineral series (Van Landuyt \& Amelinckx, 1975). (B): bastnäsite; (S): synchysite. $\mathrm{d}=\mathrm{CeF}$ layer; $\mathrm{e}=\mathrm{CO}_{3}$ layer $; \mathrm{f}=$ Ca layer and $\mathrm{g}=\mathrm{CO}_{3}$ layer between $\mathrm{Ca}$ and $\mathrm{CeF}$ layers.

The structure of parasite could be described as an alternation of $\mathrm{Ca}, \mathrm{CeF}$ and carbonate planes, all perpendicular to three-fold axis. According to the orientation of the $\mathrm{CO}_{3}$ groups within a carbonate plane, two type of carbonate layer can be distinguished, namely $e$ and $g$ (Fig. 2). The planes formed by the $\mathrm{CO}_{3}$ groups occur between the $\mathrm{CeF}$ and Ca layers and their internal structure alternate periodically from $e$ to $g$. Therefore, the structure of the mineral may be described in terms of two basic layers (Fig. 2): CeF-e-CeF and g-Ca, both constituting the parisite units (BS). The orientation of the units stacked along the $c$ direction and the periodic variation in the orientation of the $\left[\mathrm{CO}_{3}\right]$ groups result in complex polytypic structures. Five parisite polytypes could coexist in the same crystal and there are mixtures of structural layers and syntaxial intergrowth, 
constituting a polycrystal with local order and integral disorder.

The syntax among minerals of the bastnäsite group is not universal and pure phases without syntax have been found (Mariano, 1989). Syntaxial intergrowth is the most common and thirty- two types of mixed-layer components and polytypes have been observed (Van Landuyt \& Amelinckx, 1975; Meng et al., 1995, 1996, 1997, 2001a, 2001b; Wu et al., 1997, 1998a, 1998b, 2000). The formulas of the mixed layer components can be expressed as $(m+n)$ Ce $\left(\mathrm{CO}_{3}\right)$ F. $n \mathrm{CaCO}_{3}(m \geq n)$, where the $m$ and $n$ values vary as presented former. The structure of parisite had not been completely determined due to its complexity (Meng et al., 2001b).

\section{Study area, materials and methods}

\subsection{Geological Setting}

The Fazenda Varela carbonatite was identified by Scheibe (1979) as part of the Lages alkaline district. This district consists of numerous bodies of ultrabasic and alkaline rocks distributed over an area of 1,200 $\mathrm{km}^{2}$, called the Lages dome. This dome intrudes into the sedimentary rocks and basalts of the Paraná Basin (Fig. 1). The alkaline rocks are divided into two groups (Scheibe, 1986; Dani, 1998): leucocratic alkaline rocks (phonolite, nepheline syenite and analcime trachyte) and ultrabasic rocks (olivine and melilitite lamprophyre). K-Ar datings of the alkaline rocks yielded ages between $63 \mathrm{Ma}$ and $78 \mathrm{Ma}$, and $\mathrm{Rb}$-Sr dating provided ages of $81 \pm 8$ Ma (Scheibe et al., 1985; Scheibe, 1986).
The carbonatite occurs as veins that cut the Rio Bonito Formation, a member of Guatá Group in an area of approximately 1,500 x $900 \mathrm{~m}$ (Fig. 3). The Rio Bonito sediments in the studied area consist of medium sandstone composed principally of quartz and feldspar that are affected by brecciation and metasomatism related to the carbonatite intrusion.

The main outcrop occurs in the western part of the carbonatite and was mined in the 70's for soil correction. Boulders of pure carbonatite can still be encountered at this place. This carbonatite has granular texture and high porosity. A banded structure of orthoclase-rich and carbonate-rich zones associated with sedimentary rock fragments is common (Fig. 4A). According to Scheibe (1979), a drilling hole was interrupted at a depth of $100 \mathrm{~m}$ still within a homogeneous carbonatite.

In most outcrops, the carbonatite occurs as abundant veins vertical to subvertical, without a preferred orientation, and cut the sedimentary rock, forming breccia. The thickness of the veins ranges from few millimeters up to $50 \mathrm{~cm}$ (Fig. 4B). The breccia consists of quartz-feldspathic sandstone that was affected by silicification and carbonatation. The pure carbonatite and the carbonatite veins associated with the breccia are cut by small veins filled with calcite and/or quartz. Chronological relations provide evidence that the first events were the carbonatite intrusion and the transformation of the country rock to the metasomatized breccia, followed by the formation of veins with a predominance of calcite and quartz and the development of the siliceous venular system.

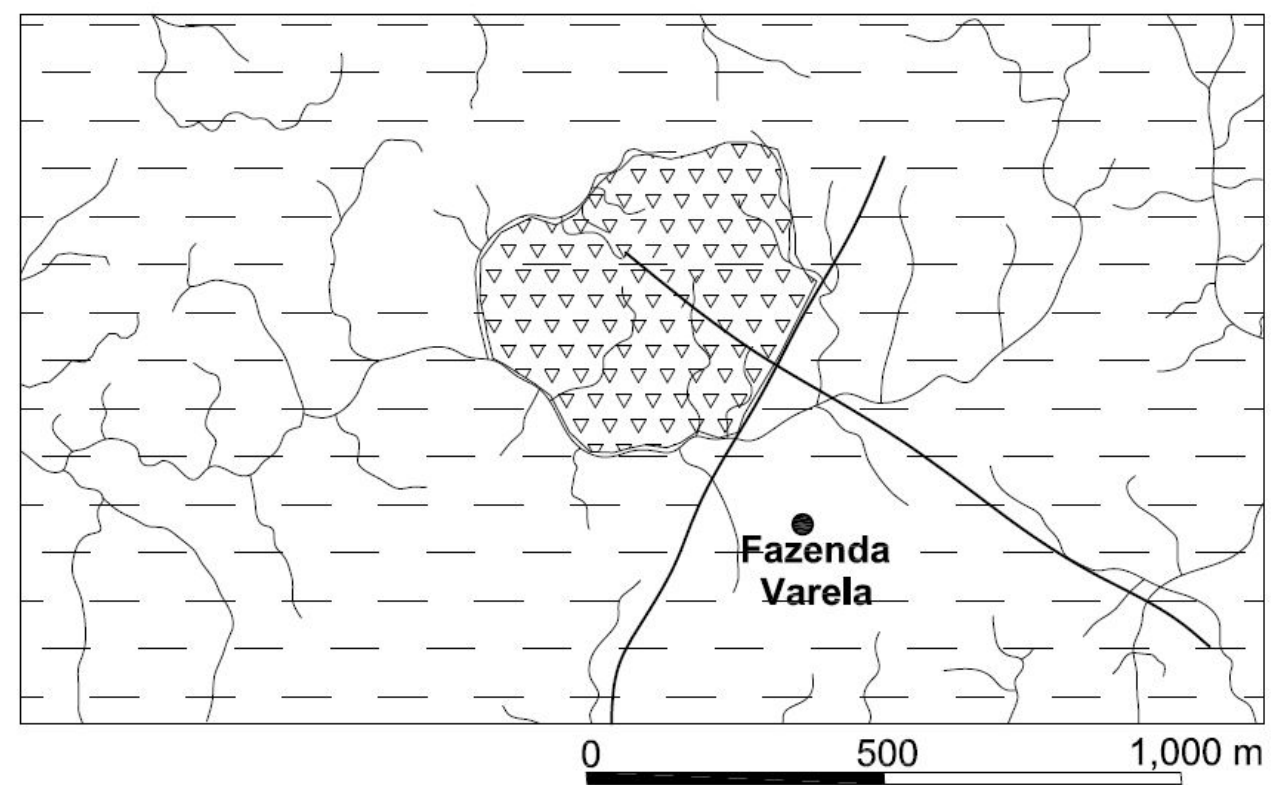

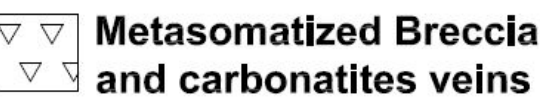

Guatá Group

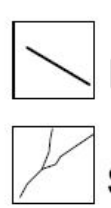

Fault

Stream

Figure 3. Geological map of the Fazenda Varela carbonatite (modified from Scheibe, 1979). 


\subsection{Geochemical data}

The Fazenda Varela carbonatite is classified as ferrocarbonatite in the Woolley \& Kempe (1989) diagram. According to Scheibe (1979), there are at least two phases of rhombohedral carbonate. Microprobe analyses made by Menegotto \& Formoso (1998) show that the most abundant carbonate is Fe-dolomite. According to Scheibe (1979), the mineralogical composition (ankerite, barite and REE fluorcarbonate) associated with the high concentrations of REE and the high $\mathrm{Ba} / \mathrm{Sr}, \mathrm{Nb} / \mathrm{Ta}$ and $\mathrm{Th} / \mathrm{U}$ ratios indicate that carbonatite was formed in the final stages of a fractionation process. The high LREE concentration relative to the HREE in the Fazenda Varela analyses is characteristic of carbonatite rocks whatever of their origin (partial melting of upper mantle, fractional crystallization or immiscibility). According to Scheibe (1979), the $\mathrm{Sr}^{87} / \mathrm{Sr}^{86}$ ratio (0.71) may indicate crustal contamination or derivations from a mantle with high initial $\mathrm{Sr}^{87} / \mathrm{Sr}^{86}$ ratio, but further analyses are required to confirm this interpretation. Based on Taylor et al. (1967) and Deines \& Gold (1973), Scheibe (1979) also concluded that Fazenda Varela $\mathrm{C}$ and $\mathrm{O}$ isotope ratios indicate that this carbonatite formed in a subvolcanic environment.

\subsection{Methods}

Seventh rock samples were collected in the western part of the carbonatite body (Fig. 3). Optical microscopy of thin sections was used to identify different paragenesis. The same samples were also analyzed by X-ray diffractometry, energy dispersion spectroscopy (EDS) and electron microprobe. The X-ray diffractometry were performed using Siemens D-5000 equipment, with $\mathrm{Cu}-\mathrm{K} \alpha$ radiation and $\mathrm{Ni}$ filter, in the range of $2^{\circ}$ and $80^{\circ} 2 \theta$, with velocity of $2^{\circ} 2 \theta$ per second. A concentrate of heavy minerals (sample CFV16) containing parisite, barite and apatite was also analyzed by this technique. This concentrate was obtained using diiodomethane (d $=3.325$ ) and the Frantz isodynamic magnetic separator $\left(15^{\circ}\right.$ of lateral inclination and $25^{\circ}$ of vertical inclination, with a current of $0.4 \mathrm{~A}$ ). EDS analyzes were made using a JEOL-JSM5800 scanning electron microscope (SEM) with a voltage of $20 \mathrm{kV}$ and spot size of $5 \mu \mathrm{m}$. These analyzes were performed at Centro de Microscopia Eletrônica (CME-UFRGS). The electron microprobe data were obtained in thin sections (CFV16 and CFV17 samples) at the CNRS/Université d'Orléans ISTO Laboratory (France) with a Cameca SX50 device, using a voltage of $15 \mathrm{kV}$ with spot size of $1 \mu \mathrm{m}$.

The whole rock analyzes, using ICP-MS, were performed at ACME Analytical Laboratories Ltda. (Canada). The analytical data were processed using Geoplot, Excel and Minfile programs. As there are many geochemical data on carbonatites in the literature, we analyzed three representative samples (CFV14, CFV16 and CFV17), only for our control. In addition, 14 sam- ples of the homogeneous breccia (without carbonatite veins) were analyzed in order to investigate their potential as REE ore. Representative breccias analyzes (BFV02, BFV05, BFV06, BFV07, BFV10 e BFV15) are presented in table 2.

\section{Results}

\subsection{Mineralogy and REE contents of Fazenda Varela car- bonatite and associated breccia}

The carbonatite, even in the veins of small thickness, has a granular texture that essentially consists of carbonates that crystallize in two stages. The carbonates from the first stage are magmatic and form rhombohedral grains, with approximately $0.4 \mathrm{~mm}$ (Fig. 4C-D). These grains are zoned and their inner bands are more ferrous (ankerite and Fe-dolomite) than those on the edge (Fe-dolomite, dolomite or, subordinately, calcite). Fe and Mn bearing impurities highlight the carbonate zonation and clouded their core crystals. Orthoclase, pyrite, and quartz are also magmatic minerals from the first stage. Orthoclase is often euhedral or subhedral (Fig. 4D), rarely twinned, with dimensions between 0.1 and $0.4 \mathrm{~mm}$. Orthoclase is included in the carbonates of the two generations (Fig. 4C-4D) and is frequently hydrothermalized, sometimes rounded and with corroded edges. Pyrite forms euhedral crystals with 0.5 to $2 \mathrm{~mm}$, which are often pseudomorphosed by iron oxide. The quartz crystals occur principally in cavities or veins associated with apatite and carbonate from the second stage, but sometimes they are included in the carbonate from the first stage. Rare crystals of pyrochlore and monazite were observed with SEM.

The carbonatite was strongly affected by late- and post-magmatic processes. Fluids percolated through the fractures and grain boundaries, forming hydrothermal domains constituted by carbonates of the second generation, barite, quartz, and apatite, all of which have thin size. The second generation of carbonate is composed of calcite, Fe-dolomite and parisite-(Ce). The first two occur (a) as small rhombohedral crystals in the interstices between the carbonate crystals of the first stage (Fig. 4D), (b) on the rims of the carbonate crystals of the first stage (Fig. 4D), and (c) in the hydrothermal domains (Fig. 4C, between the ankerite crystals). In this case, the second stage minerals display irregular contours and contain many mineral inclusions. The parisite-(Ce), described by Scheibe (1979) as synchysite, was the last carbonate to crystallize. Its crystals are light brown in natural light and present birefringence of the third order. They are better developed than the other two carbonates and are frequently $0.4 \mathrm{~mm}$ in size. They occur with fibrous habits and elongated forms (Fig. 4C), crystallized either partially following the boundaries of the ankerite crystals and partially penetrating into the matrix of hydrothermal minerals. They can be also totally in the hydrothermal 
matrix, where they often have fibroradiated habits and seem to replace and/or encompass the thinner sized minerals. These characteristics, which are related to the pervasive hydrothermalism, covering/replacing various minerals, can be clearly observed in the SEM images (Fig. 4G). The parisite-(Ce) also occurs in veins with calcite and hematite, which cut the carbonatite irregularly.

Barite (Fig. 4C) occurs as anhedral crystals that are often rounded, with sizes ranging from 0.05 to 100 $\mathrm{mm}$. Apatite forms a crypto- to microcrystalline mass, with euhedral or acicular crystals with a size of approximately $0.01 \mathrm{~mm}$, which are frequently associated with anhedral crystal of hydrothermal quartz filling veins. It is noteworthy that EDS analyses show the presence of chlorine in apatite. Rare crystals of aluminum strontium phosphate (goyasite?) were observed in the SEM analyses. This phase probably belongs to the hydrothermal stage.

In metasomatized breccia, even in the most homogeneous parts (i.e. without carbonatite veins), it is possible observe an intense silicification (Fig. 4F), which sometimes completely erases (Fig. 4E) the grain boundaries of the quartz and feldspar crystals of the original sedimentary rock. Well-developed carbonate crystals from the first stage (Fig. 4E) that displays zones well-marked by impurities than those observed in carbonatite samples, are commonly observed in the siliceous mass. As well as the carbonatite, the breccia is cut by hydrothermal veins with calcite, hematite, and parisite-(Ce).

The sample CFV17 (Tab. 2) displays a REE pattern distribution (Fig. 5) typical of carbonatite and characterized by high LREE contents and strong fractionation ( $\mathrm{LaN} / \mathrm{YbN}=1.343$ ). The samples CFV14 and CFV16 are also rich in LREE, but have much lower fractionation ( $\mathrm{LaN} / \mathrm{YbN}=72$ and 22, respectively). These two samples have relatively flat HREE distribution pattern, and $\mathrm{GdN} / \mathrm{YbN}=2.02$ (CFV14) and 2.22 (CFV16). The origin of anomalous concentrations of $\mathrm{P}$ and HREE of these samples (Tab. 2) are most likely related to the presence of hydrothermal apatite.

Table 2 shows representative analyses of the metasomatized breccia (BFV02, BFV05, BFV06, BFV07, BFV10 and BFV15). Four samples have REE + Y ranging from 2,486ppm to 4,139ppm, whereas two samples show low values (506 and 696ppm). As well as in the carbonatite, La and Ce are the most abundant REE in the breccia. The concentrations of HREE and Y are very low, which is corroborated by the petrographic evidence (Fig. 4F) that the same hydrothermal fluid that concentrates REE in carbonatite formed the breccia REE-mineralization.

Table 2. Whole rock chemical analyses (wt \%) of Fazenda Varela carbonatite (CFV14, CFV16 and CFV17) and associated metasomatized breccia (BFV02, BFV05, BFV06, BFV07, BFV10, BFV15).

\begin{tabular}{|c|c|c|c|c|c|c|c|c|c|}
\hline Sample & CFV14 & CFV16 & CFV17 & BFV02 & BFV05 & BFV06 & BFV07 & BFV10 & BFV15 \\
\hline \multicolumn{10}{|l|}{ (wt\%) } \\
\hline $\mathrm{SiO}_{2}$ & 4.81 & 2.96 & 0.69 & 61.43 & 65.57 & 56.67 & 54.57 & 53.43 & 57.59 \\
\hline $\mathrm{Al}_{2} \mathrm{O}_{3}$ & 1.52 & 1.71 & 0.22 & 7.65 & 9.73 & 15.39 & 13.27 & 15.6 & 16.11 \\
\hline $\mathrm{Fe}_{2} \mathrm{O}_{3 \mathrm{~T}}$ & 12.79 & 12.25 & 10.72 & 19.21 & 3.20 & 4.89 & 7.41 & 7.33 & 7.66 \\
\hline $\mathrm{MnO}$ & 1.77 & 1.75 & 1.47 & 0.05 & 0.37 & 0.89 & 1.15 & 1.07 & 0.92 \\
\hline $\mathrm{MgO}$ & 5.46 & 5.14 & 8.05 & 0.07 & 0.37 & 0.46 & 0.88 & 0.88 & 0.11 \\
\hline $\mathrm{CaO}$ & 32.1 & 33.29 & 20.59 & 0.02 & 6.23 & 2.34 & 1.44 & 0.89 & 0.03 \\
\hline $\mathrm{BaO}$ & 1.38 & 1.15 & $>5.58$ & 0.87 & 0.60 & 0.98 & 4.10 & 1.74 & 1.27 \\
\hline $\mathrm{SrO}$ & 0.90 & 1.27 & 0.26 & 0.01 & 0.08 & 0.04 & 0.30 & 0.07 & 0.04 \\
\hline $\mathrm{Na}_{2} \mathrm{O}$ & 0.40 & 0.58 & 0.05 & 0.13 & 0.25 & 0.29 & 0.25 & 0.36 & 0.33 \\
\hline $\mathrm{K}_{2} \mathrm{O}$ & 0.63 & 0.45 & 0.14 & 5.24 & 6.46 & 13.25 & 10.85 & 13.17 & 13.06 \\
\hline $\mathrm{TiO}_{2}$ & 0.08 & 0.04 & $<0.01$ & 0.69 & 0.20 & 0.16 & 0.42 & 0.06 & 0.04 \\
\hline $\mathrm{P}_{2} \mathrm{O}_{5}$ & 11.33 & 13.91 & 0.03 & 0.07 & 0.07 & 0.11 & 0.31 & 0.21 & 0.03 \\
\hline $\mathrm{CO}_{2}$ & 22.20 & 21.47 & 35.84 & 0.40 & 4.69 & 1.98 & 1.61 & 1.06 & 0.15 \\
\hline $\mathrm{F}$ & $>1.00$ & $>1.00$ & 0.17 & 0.01 & 0.03 & 0.04 & 0.06 & 0.05 & 0.04 \\
\hline Total & 96.37 & 96.97 & 83.82 & 95.85 & 97.85 & 97.49 & 96.62 & 95.92 & 97.38 \\
\hline \multicolumn{10}{|l|}{ (ppm) } \\
\hline $\mathrm{Y}$ & $1,101.90$ & $1,738.70$ & 50.40 & 10.80 & 17.40 & 21.30 & 34.70 & 26.60 & 67.80 \\
\hline $\mathrm{La}$ & 384.50 & $2,324.50$ & $4,285.70$ & 58.10 & 182.10 & 820.00 & 572.40 & $1,271.70$ & 937.90 \\
\hline $\mathrm{Ce}$ & 693.50 & $4,129.70$ & $5,519.20$ & 338.70 & 323.20 & $1,337.80$ & $1,777.08$ & $2,023.20$ & 776.40 \\
\hline $\operatorname{Pr}$ & 69.50 & 413.89 & 419.69 & 15.10 & 31.77 & 128.91 & 104.18 & 178.58 & 130.75 \\
\hline $\mathrm{Nd}$ & 227.10 & $1,362.90$ & $1,057.60$ & 55.50 & 103.50 & 392.20 & 334.90 & 521.40 & 440.80 \\
\hline $\mathrm{Sm}$ & 31.02 & 220.95 & 102.13 & 9.81 & 14.94 & 42.04 & 52.57 & 53.70 & 50.20 \\
\hline $\mathrm{Eu}$ & 8.73 & 78.33 & 24.74 & 2.80 & 4.40 & 10.63 & 15.28 & 13.29 & 13.98 \\
\hline $\mathrm{Gd}$ & 19.70 & 230.78 & 66.18 & 6.87 & 9.86 & 22.21 & 30.23 & 31.34 & 39.87 \\
\hline $\mathrm{Tb}$ & 2.96 & 52.64 & 5.66 & 0.85 & 1.21 & 2.35 & 3.52 & 3.22 & 4.08 \\
\hline Dy & 13.74 & 331.31 & 18.68 & 3.63 & 4.33 & 7.88 & 11.69 & 10.27 & 14.14 \\
\hline Ho & 2.54 & 72.01 & 1.91 & 0.59 & 0.60 & 0.88 & 1.38 & 1.12 & 1.97 \\
\hline $\mathrm{Er}$ & 6.66 & 174.09 & 3.62 & 1.18 & 1.47 & 2.07 & 2.77 & 2.24 & 4.10 \\
\hline $\mathrm{Tm}$ & 0.96 & 21.56 & 0.47 & 0.17 & 0.20 & 0.28 & 0.42 & 0.28 & 0.51 \\
\hline $\mathrm{Yb}$ & 5.31 & 103.97 & 3.19 & 1.46 & 1.10 & 1.87 & 2.53 & 2.11 & 2.94 \\
\hline $\mathrm{Lu}$ & 0.72 & 12.27 & 0.39 & 0.18 & 0.16 & 0.30 & 0.34 & 0.34 & 0.38 \\
\hline Total & 2,569 & 1,1268 & 1,1560 & 506 & 696 & 2,791 & 2,945 & 4,139 & 2,486 \\
\hline
\end{tabular}



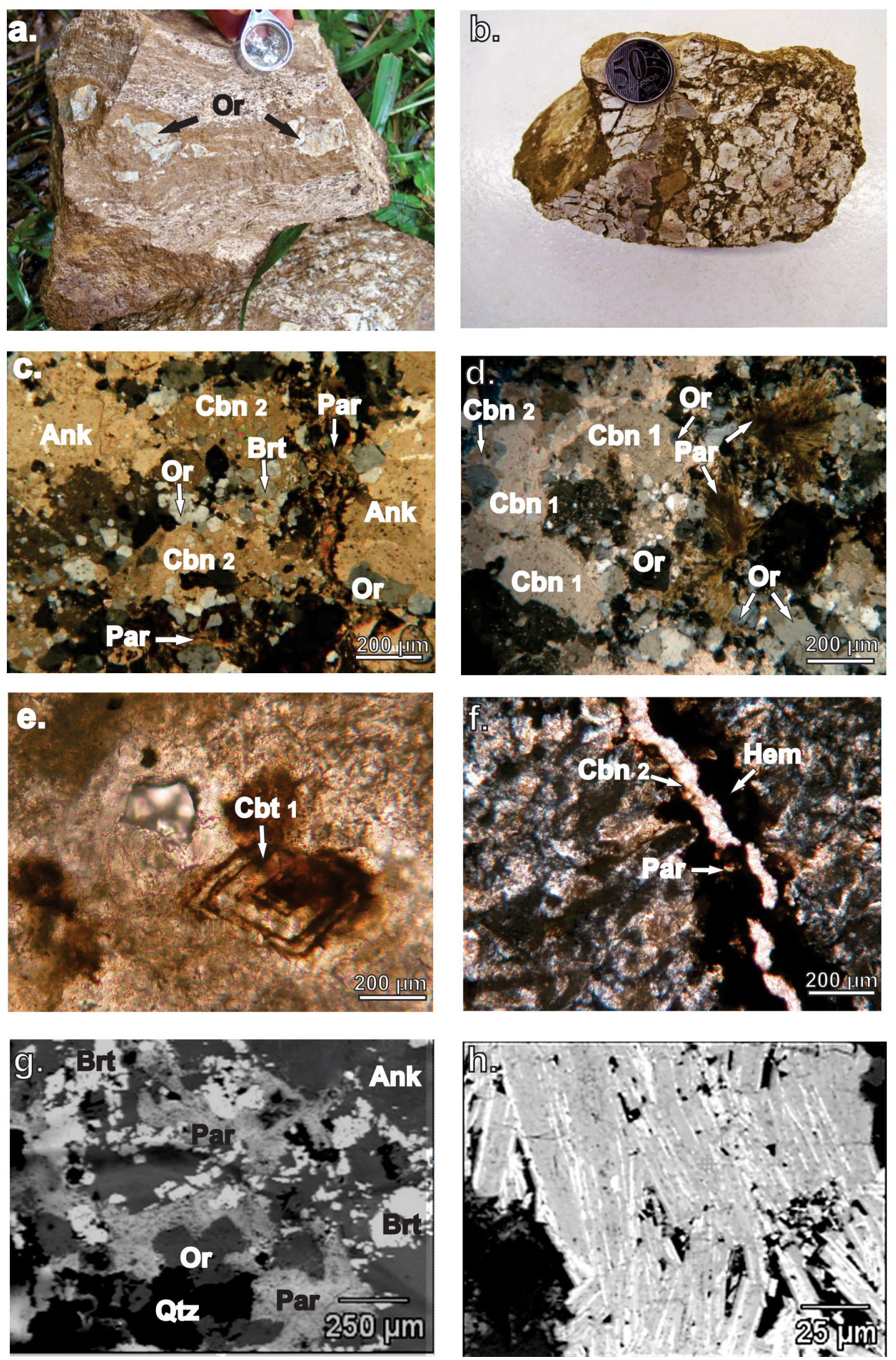

Figure 4. Fazenda Varela carbonatite: (A) Banded carbonatite sample; (B) Metasomatized breccia with portions of silicified sedimentary rock (white) and carbonatite matrix (brown); (C) Photomicrograph of carbonatite (TLCP) with rhombohedral crystals of magmatic ankerite. The fine minerals in the central part are carbonate from the second generation, barite and parisite-(Ce) with fibrous habit. All have hydrothermal origin, and parisite-(Ce) was formed on the boundary of ankerite grain; (D) Photomicrograph of carbonatite (TLCP). Note on the left side, two magmatic carbonate crystals (cbn 1) and hydrothermal interstitial carbonate (cbn 2). The central and right side is a "hydrothermal domain", note the fibroradiated parisite-(Ce) and the subhedral crystals of magmatic orthoclase included in hydrothermal minerals; (E) Photomicrograph of metasomatized breccia (TPPL) with zoned rhombohedral carbonate showing Fe-oxides inclusions highlighting the growth bands; (F) Photomicrograph of metasomatized breccia (TLCP) cut by hydrothermal veinlet fills with calcite, hematite and parisite-(Ce); (G) SEM image showing a hydrothermal domain with parisite-(Ce); (H) SEM image of banded parisite-(Ce) with syntaxial intergrowth between phases richer in Ca (gray band) and REE (white bands). Abbreviations: Ank: ankerite, Brt: barite, Cbn1: rhombohedral magmatic carbonate Cbn 2: hydrothermal carbonate, Or: orthoclase, Par: parisite-(Ce) and Qtz: quartz. TPPL: transmitted plane-polarized light, TLCP: transmitted light with crossed polars. 


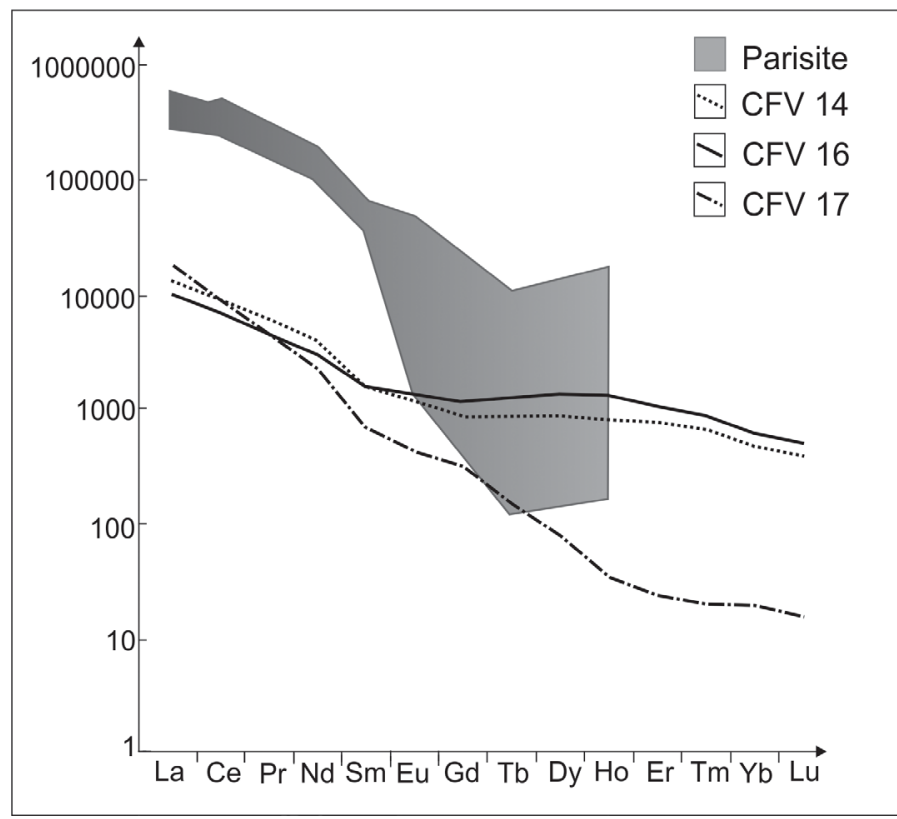

Figure 5. REE distribution pattern of Fazenda Varela carbonatite (ICP-MS) and parisite-(Ce) (Electron Micropoble) from the samples CFV14, CFV16 and CFV17. Samples normalized by C1 chondrite (Anders \& Grevesse, 1989).

\subsection{Study of the REE fluorcarbonate of Fazenda Varela carbonatite}

The X-ray diffraction analyses performed on heavy minerals (Tab. 3) present parisite and synchysite peaks. The SEM images of parisite-(Ce) (Fig. 4H) show that its crystals have gray and white phases that are oriented approximately in parallel without regular distribution patterns. Gray phases are dominant but the proportion of white and gray phases varies with magnification (Fig. 4H and Fig. 6). The chemical profiles (Fig. 6) show that the white phases are richer in REE and poorer in $\mathrm{Ca}$ in relation to the gray phases. In the white bands, $\mathrm{Ca}$ ranges from $3.45 \%$ to $19.67 \%$ (average $12.78 \%$ ), and the REE content varies from 80.33 to $96.55 \%$ (average $87.22 \%)$. In the gray bands, the Ca content varies from 15.40 to $35.81 \%$ (average $21.12 \%$ ), and the REE vary from $64.19 \%$ to $84.60 \%$ (average $78.88 \%$ ). Due to semi-quantitative character of these analyses, the given contents have just an indicative value, but these variations are significant. However, according to the relative proportions between Ca and REE, the white bands tend to have parisite compositions, and the gray bands tend to have intermediate compositions between parisite and synchysite. A few analyses display very low Ca concentrations, indicating a composition similar to that of bastnäsite.

As the banding and compositional variation exist in different scales, the electron microprobe analyses represent an average of the bands compositions under the electron bean spot size. To verify the differences in crystal compositions, cross-sections analyses were performed. Depending on the crystal dimensions each section is composed by 30 to 60 analyses. Along the profiles, variations in the composition were observed. However, these variations are generally small and there were no systematic differences between the edge and core of a crystal. The same was true among crystals of the same sample and among crystals from different samples. Table 4 shows representative analyses of the parisite-(Ce). They are consistent with those given by Ni et al. (2000).

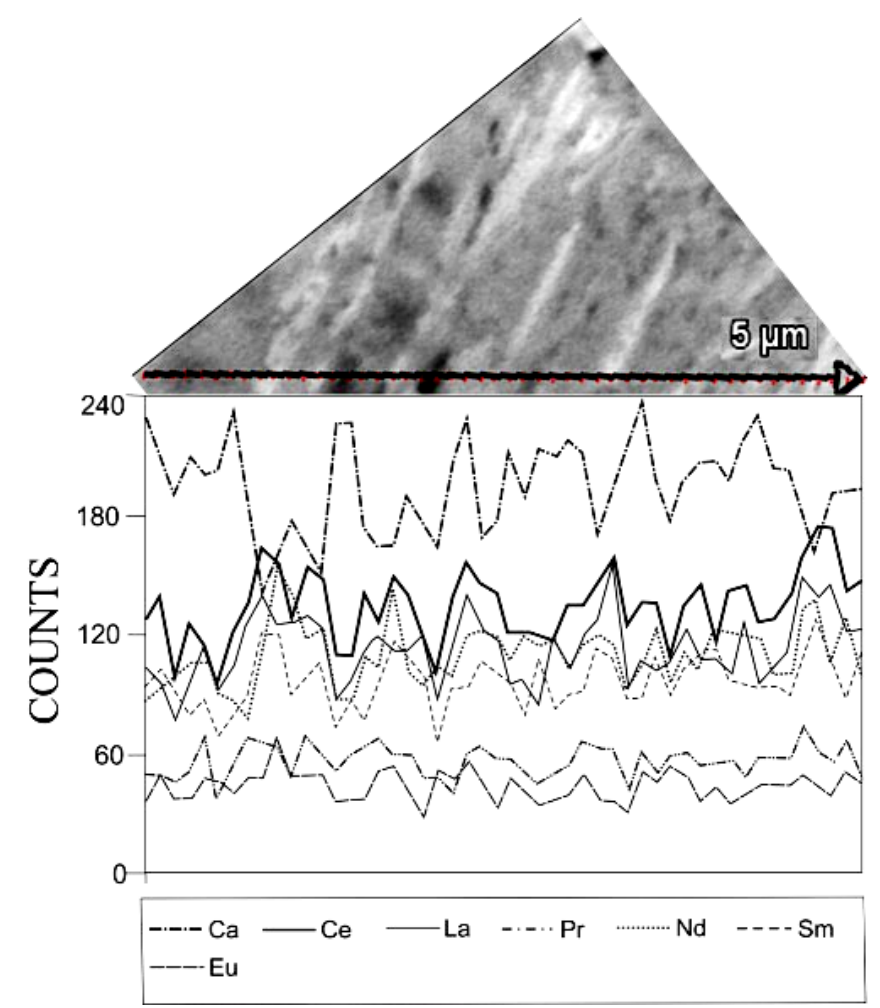

Figure 6. SEM image and chemical semi-quantitative profile along a parisite-(Ce) crystal.

Table 3. Comparison between X-ray analyzes of Fazenda Varela carbonatite heavy minerals and literature data.

\begin{tabular}{|c|c|c|c|c|c|c|}
\hline \multicolumn{2}{|c|}{ Samples } & \multicolumn{4}{|c|}{ Literature Data } & \multirow{2}{*}{ Mineral } \\
\hline $2 \theta$ & $\mathrm{d}(\mathrm{hkl})$ & $\mathrm{N} / \mathrm{N}$ & hkl & $\mathrm{d}(\mathrm{hkl})$ & $\mathrm{I} / \mathrm{I} 0 * 100 . \% \%$ & \\
\hline $\begin{array}{l}6.58 \\
9.64 \\
19.3 \\
19.62 \\
24.88 \\
24.96 \\
25.5 \\
25.88 \\
26.62 \\
28.72 \\
31.96 \\
32.9 \\
\end{array}$ & $\begin{array}{c}13.42 \\
9.17 \\
4.6 \\
4.52 \\
3.58 \\
3.57 \\
3.49 \\
3.44 \\
3.35 \\
3.11 \\
2.8 \\
2.72 \\
\end{array}$ & $\begin{array}{l}1 \\
1 \\
3 \\
3 \\
2 \\
2 \\
2 \\
2 \\
3 \\
1 \\
1 \\
3 \\
\end{array}$ & $\begin{array}{lll}0 & 0 & 2 \\
0 & 0 & 2 \\
0 & 0 & 6 \\
0 & 0 & 4 \\
3 & 1 & -1 \\
3 & 1 & -1 \\
0 & 0 & 2 \\
2 & 1 & 0 \\
1 & 0 & 2 \\
2 & 1 & 1 \\
1 & 2 & 1 \\
3 & 0 & 0\end{array}$ & $\begin{array}{l}13.97 \\
9.14 \\
4.66 \\
4.59 \\
3.56 \\
3.55 \\
3.46 \\
3.44 \\
3.32 \\
3.1 \\
2.81 \\
2.72 \\
\end{array}$ & $\begin{array}{l}100 \\
100 \\
81.9 \\
44.7 \\
52.1 \\
87.7 \\
62.5 \\
97.9 \\
65.2 \\
100 \\
100 \\
52.5 \\
\end{array}$ & $\begin{array}{l}\text { parisite } \\
\text { synchysite } \\
\text { parisite } \\
\text { synchysite } \\
\text { synchysite } \\
\text { parisite } \\
\text { apatite } \\
\text { barite } \\
\text { barite } \\
\text { barite } \\
\text { apatite } \\
\text { apatite }\end{array}$ \\
\hline
\end{tabular}


Table 4. Chemical composition (wt \%) and structural formulas of parisite-(Ce).

\begin{tabular}{|c|c|c|c|c|c|c|c|c|}
\hline & \multicolumn{3}{|c|}{ Parisite 1} & \multicolumn{3}{|c|}{ Parisite 2} & \multicolumn{2}{|c|}{ Parisite 3} \\
\hline & $1 \mathrm{a}$ & $1 \mathrm{~b}$ & $1 c$ & $2 \mathrm{a}$ & $2 b$ & $2 c$ & $3 a$ & $3 c$ \\
\hline $\mathrm{CaO}$ & 13.5 & 9.15 & 14.8 & 13.11 & 13.94 & 14.82 & 11.72 & 15.11 \\
\hline $\mathrm{SrO}$ & 0.69 & 0.23 & 1.21 & 1.14 & 0.97 & 0.61 & 0.76 & 0.53 \\
\hline $\mathrm{BaO}$ & 2.06 & 2.66 & 0 & 2.88 & 0.41 & 0.02 & 0.78 & 1.65 \\
\hline $\mathrm{MgO}$ & 0 & 0.11 & 0 & 0.08 & 0 & 0.01 & 0 & 0 \\
\hline $\mathrm{PbO}$ & 0.13 & 0.14 & 0 & 0 & 0 & 0 & 0.22 & 0.08 \\
\hline $\mathrm{Y}_{2} \mathrm{O}_{3}$ & 0.45 & 0.38 & 0.1 & 0.21 & 0.39 & 1.74 & 0.42 & 0.38 \\
\hline $\mathrm{La}_{2} \mathrm{O}_{3}$ & 13.89 & 8.61 & 14.99 & 12.54 & 14.16 & 12.39 & 15.81 & 14.05 \\
\hline $\mathrm{Ce}_{2} \mathrm{O}_{3}$ & 26.07 & 34.72 & 24.77 & 28.13 & 25.94 & 24.86 & 28.15 & 25.17 \\
\hline $\mathrm{Nd}_{2} \mathrm{O}_{3}$ & 8.31 & 5.49 & 8.11 & 7.33 & 8.17 & 7.16 & 7.82 & 7.15 \\
\hline $\mathrm{Sm}_{2} \mathrm{O}_{3}$ & 1.1 & 0.6 & 0.82 & 0.72 & 0.96 & 0.87 & 0.78 & 0.89 \\
\hline $\mathrm{Dy}_{2}^{2} \mathrm{O}_{3}^{3}$ & 0 & 0.06 & 0.02 & 0 & 0 & 0.09 & 0 & 0.14 \\
\hline $\mathrm{Gd}_{2} \mathrm{O}_{3}$ & 0.58 & 0.05 & 0.19 & 0.25 & 0.61 & 1.05 & 0.84 & 0.23 \\
\hline $\mathrm{Er}_{2} \mathrm{O}_{3}$ & 0 & 0 & 0.58 & 0 & 0 & 0.07 & 0 & 0 \\
\hline $\mathrm{P}_{2} \mathrm{O}_{5}$ & 0.67 & 1.29 & 0.35 & 0.58 & 0.52 & 0.54 & 0.39 & 2.14 \\
\hline $\mathrm{F}^{5}$ & 4.51 & 2.82 & 4.55 & 3.79 & 4.7 & 6.06 & 5.22 & 5.04 \\
\hline $\mathrm{CO}_{2}{ }^{*}$ & 27.48 & 29.43 & 27.43 & 28.31 & 27.26 & 25.68 & 26.65 & 26.86 \\
\hline Total & 99.44 & 95.74 & 97.92 & 99.07 & 98.03 & 95.97 & 99.56 & 99.42 \\
\hline $\mathrm{Ca}$ & 1.25 & 0.96 & 1.37 & 1.22 & 1.3 & 1.38 & 1.13 & 1.33 \\
\hline $\mathrm{Sr}$ & 0.03 & 0.01 & 0.06 & 0.06 & 0.05 & 0.03 & 0.04 & 0.03 \\
\hline $\mathrm{Ba}$ & 0.07 & 0.1 & 0 & 0.1 & 0.01 & 0 & 0.03 & 0.05 \\
\hline $\mathrm{Mg}$ & 0 & 0.02 & 0 & 0.01 & 0 & 0 & 0 & 0 \\
\hline $\mathrm{Pb}$ & 0 & 0 & 0 & 0 & 0 & 0 & 0 & 0 \\
\hline $\mathrm{Y}$ & 0.02 & 0.02 & 0 & 0.01 & 0.02 & 0.08 & 0.02 & 0.02 \\
\hline $\mathrm{La}$ & 0.44 & 0.31 & 0.48 & 0.4 & 0.45 & 0.4 & 0.52 & 0.43 \\
\hline $\mathrm{Ce}$ & 0.82 & 1.25 & 0.78 & 0.9 & 0.83 & 0.79 & 0.93 & 0.76 \\
\hline $\mathrm{Nd}$ & 0.26 & 0.19 & 0.25 & 0.23 & 0.25 & 0.22 & 0.25 & 0.21 \\
\hline $\mathrm{Sm}$ & 0.03 & 0.02 & 0.02 & 0.02 & 0.03 & 0.03 & 0.02 & 0.03 \\
\hline Dy & 0 & 0 & 0 & 0 & 0 & 0 & 0 & 0 \\
\hline Gd & 0.02 & 0 & 0.01 & 0.01 & 0.02 & 0.03 & 0.03 & 0.01 \\
\hline $\mathrm{Er}$ & 0 & 0 & 0 & 0 & 0 & 0 & 0 & 0 \\
\hline $\mathrm{P}$ & 0.05 & 0.11 & 0.03 & 0.04 & 0.04 & 0.04 & 0.03 & 0.15 \\
\hline$\Sigma$ Charges & 7.72 & 8.12 & 7.63 & 7.7 & 7.71 & 7.67 & 7.86 & 7.89 \\
\hline $\mathrm{F}$ & 1.23 & 0.81 & 1.23 & 1.03 & 1.28 & 1.65 & 1.45 & 1.41 \\
\hline $\mathrm{C}$ & 3.24 & 3.65 & 3.2 & 3.33 & 3.21 & 3.01 & 3.2 & 3.24 \\
\hline
\end{tabular}

As the composition is similar with that of parisite, the structural formulas were calculated based on three cations. The $\mathrm{CO}_{2}$ was calculated based on the charge balance. In all the analyses, Ce was the dominant cation, thus requiring the use of the suffix "- (Ce)" (Bayliss \& Levinson, 1988). The preferential order for REE incorporation was Ce> La $>\mathrm{Nd}>>$ HREE $\sim$ Y. The concentration of the LREE (La, Sm) ranged from 45 to $52.5 \mathrm{wt} \%$. An ideal parisite-(Ce, La) has a LREE concentration of $\sim 60 \mathrm{wt} \%$. The value of REE + Y in the formula was generally between 1.50 and 1.60 , lower than the ideal value (REE $+Y=2)$. Calcium was the dominant divalent cation, and its value in the structural formula exceeded the expected value $(\mathrm{Ca}=1)$ in practically all analyses. Thus, the analyses with lower Ca values tended to have higher REE values. However, there was no statistical correlation between Ca and REE. Therefore it is not possible to interpret the occurrence of substitution of $\mathrm{REE}$ by $\mathrm{Ca}$. Ba and Sr occurred in small quantities, and the F concentrations varied widely, from 3.79 to 6.06 wt $\%$, corresponding to a structural formula of 1.03 to 1.65 (the value in the ideal formula is $F=2$ ).

The distribution pattern of REE in parisite-(Ce) (Fig. 5), although increased by a factor of approximately 100 times, was very similar to the REE pattern of the carbonatite, especially for the LREE, which are the main REE in parisite and carbonatites. In parisite with higher HREE concentrations, the distribution pattern of the HREE was very similar to that of the carbonatite. In figure 7, the fluorcarbonate from Fazenda Varela is compared with the parisite from Muso, Colombia (Ni et al., 2000), synchysite from the Main Sayan Fault in Russia (Savel'eva \& Karmanov, 2008), ceric synchysite from Markersbach, Germany (Förster, 2001) and hydrothermal parisite and synchysite from Barra do Itapirapuã, Brazil (Ruberti et al., 2008). This comparison highlights the similarity of the Fazenda Varela parisite to other natural parisites, as well as its richness in Ce. 


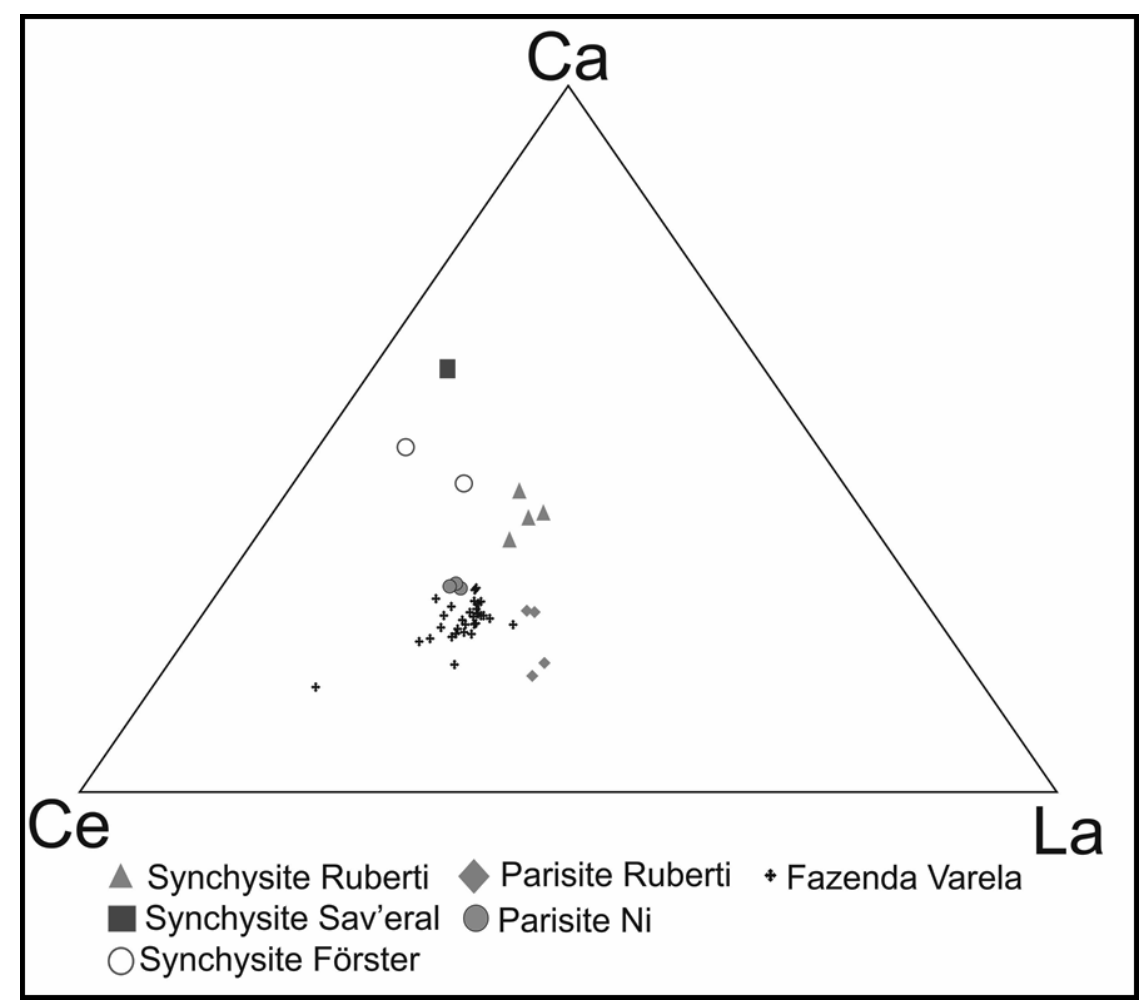

Figure 7. Ca-Ce-La (wt\%) data, comparing the Fazenda Varela parisite with Ni et al. (2000) parisites; Savel'eva \& Karmanov (2008) synchysites; Förster (2001) ceric synchysites and with the hydrothermal parisite and synchysite from Barra do Itapirapuã (Ruberti et al., 2008).

\section{Discussion}

The most important Fazenda Varela parisite-(Ce) feature is the variation in its chemical composition, notably by Ca and REE. These variations have been described for bastnäsite, synchysite and parisite and are associated with the hydrothermal carbonatite mineralization of Barra do Itapirapuã (Ruberti et al., 2008). These authors found that these minerals are composed of mixed layers with different proportions of bastnäsite $\left(\mathrm{CeFCO}_{3}\right)$ and synchysite $\left(\mathrm{CeFCO}_{3} \cdot \mathrm{CaCO}_{3}\right)$. In Fazenda Varela, the EDS analyses confirmed the existence of syntactic growth, but with some characteristics distinct from those described by Ruberti et al. (2008), such as the existence of bands that repeats with every increase in the observed SEM scale. Thus, there are not recognizable homogeneous phases. The existence of the bastnäsite component (a mineral without $\mathrm{Ca}$ ) indicates a composition with $\mathrm{Ca}<1$, which does not occur; instead, there is a tendency of excess Ca in the mineral. A bastnäsite component also indicates the tendency of increased contents of REE in respect to parisite or synchysite, which also does not occur; the REE contents are lower than expected. The contents of the main cations range from a composition ( $\mathrm{Ca}=0.96$; $\mathrm{REE}=1.79$ ) close to an ideal parisite ( $\mathrm{Ca}=1 ; \mathrm{REE}=2)$ to an intermediate composition between parisite and synchysite. Thus, emphasizing the coherence among the XRD, EDS and electron microprobe data, the mineral is classified as parisite-(Ce) with particular characteristics represented by an excess of $\mathrm{Ca}$ and deficiencies of REE (related to syntactic growth with synchysite) and $\mathrm{F}$.
Carbonatites are typically anomalous REE-bearing rocks, with preponderant LREE. Composition characterized by relative high LREE content and trace quantities of HREE and Y occur: in early crystallized, independent REE minerals; in minerals originating from hydrothermal events; and, less frequently, in supergene products of weathering. In many cases, the distinction between what constitute primary mineralization and hydrothermal REE mineralization in carbonatites is debatable (Mariano \& Mariano, 2012), such as in Mountain Pass, where parisite is interpreted as hydrothermal (Chakhmouradian \& Wall, 2012). In cases where the mineralization is well characterized as hydrothermal, such as in Barra do Itapirapuã (Ruberti et al., 2008), the REE fluorcarbonates paragenesis is more complex and occurs with associated fluorite. There is no record in the literature of REE mineralization associated with carbonatite solely with parisite, whatever the origin of this mineral i. e. magmatic or hydrothermal. The only case of REE hydrothermal mineralization where parisite is the main REE mineral is Snowbird mine (USA), where it is a byproduct of exploitation of hydrothermal fluorite veins related to granite (Metz et al., 1985; Mariano \& Mariano, 2012). Fazenda Varela is, therefore, a special case of hydrothermal REE mineralization associated with carbonatite. The characteristics found in Fazenda Varela parisite-(Ce) certainly reflect the conditions of a particular environment.

Some classical concepts about the behavior of REE in a hydrothermal environment were corroborated by thermodynamic calculations; however, these calculations did not take into account changes in the dielectric 
behavior of water as a function of temperature. Because there is commonly a close association between hydrothermal REE mineralization and fluorite, one of the concepts is that in environments in which the REE are concentrated to economic or potentially economic levels, they are invariably transported as fluoride complexes. Another concept is the lesser LREE mobility relative to HREE. These ideas are being reviewed by experimental studies on the speciation of REE in fluoride-and chlorine-bearing aqueous solutions in temperatures up to $300^{\circ} \mathrm{C}$ (Williams-Jones et al., 2012). These experiments established that: (i) the LREE are more hydrothermally mobile than the HREE, (ii) the REE form stable complexes with fluorine and chlorine ions at high temperatures and (iii) the LREE complexes with these ligands are more stable than their HREE equivalents. The same authors reproduced the ore deposition conditions in systems where aliquots of REE-bearing fluid (with $10 \mathrm{wt} \% \mathrm{NaCl}, \mathrm{pH} 4.5$, cooling from $400^{\circ}$ to $200^{\circ} \mathrm{C}$ ) passed through and reacted with a phosphorous-bearing nepheline syenite. As the reaction starts, monazite, containing equal proportions of each REE, precipitated. With progressive fluid-rock interaction, the $\mathrm{pH}$ buffering capacity of the rock decreased. Consequently, the LREE were leached and precipitated farther along the path of the fluid at lower temperatures.

Textural evidences and parasite-(Ce) chemical composition, with respect to $\mathrm{F}$ and $\mathrm{Ca}$, indicate that this mineral crystallized in an advanced stage of hydrothermalism from a fluid with low $\mathrm{F}$ activity and high $\mathrm{Ca}$ and $\mathrm{CO}_{3}{ }^{2-}$ activities. Because of the late character, it is not expected that this fluid matches to the residual magmatic volatiles without any or with very little interaction with the rock. Field and petrographic data evidences show that the mineralizing fluid is late and have interacted intensively with the rock during the rise. This interaction should have resulted in preferential partitioning of LREE for the fluid in the form of chlorine complex. The parisite deposition may have occurred through the following reaction (1):

$\mathrm{Ca}^{2+}+2 \mathrm{REECl}^{2+}+2 \mathrm{HF}+2 \mathrm{HCO}_{3}^{-}=\mathrm{CaREE}_{2}\left(\mathrm{CO}_{3}\right)_{2} \mathrm{~F}_{2}+2 \mathrm{H}^{+}+2 \mathrm{Cl}$

Such reaction is favored by $\mathrm{pH}$ and $\mathrm{HCO}_{3}^{-}$activity increase and a decrease in the $\mathrm{Cl}^{-}$activity. In Bayan Obo, the bastnäsite deposition was induced by the dissolution of dolomite (Williams-Jones et al., 2012). By analogy, in Fazenda Varela, a similar mechanism could be the dissolution of ankerite by the following reaction (2):

$2 \mathrm{H}^{+}+\mathrm{CaFe}\left(\mathrm{CO}_{3}\right)_{2}=\mathrm{Ca}^{2+}+\mathrm{Fe}^{2+}+2 \mathrm{HCO}_{3}{ }^{-}$

Alternatively, the mechanism could be the result of a $\mathrm{pH}$ increase by an alkaline water supply obtained from the enclosing sedimentary rock. It is a very plausible hypothesis given the geological context and the fact that the parisite-(Ce) formation occurred at a late stage of hydrothermalism, when external fluid input could be very effective.

\section{Conclusions}

The Fazenda Varela ferrocarbonatite has ankerite and Fe-dolomite as its main magmatic minerals; orthoclase, pyrite and quartz occur subordinately. The apatite concentrations are observed in some samples, but require further study. This ferrocarbonatite had been strongly affected by late- and post-magmatic hydrothermal events. The fluids percolated through fractures and grain boundaries and formed domains composed of barite, apatite, quartz, calcite, ferrodolomite and parisite-(Ce). The parisite-(Ce) is composed of well-developed fibrous to fibroradiated crystals that occur into the hydrothermal domain.

The REE mineralization (Ce and La) in carbonatite is hydrothermal and consists solely of disseminated parisite-(Ce), without associated fluorite. The country rock is a feldspathic quartz sandstone from the Rio Bonito Formation that was strongly affected by brecciation and metasomatism due to the carbonatite intrusion. In the portions closest to the intrusion, the mineralization consists of the ferrocarbonatite that constitutes the breccia matrix. In the more distant parts, without carbonatite veins/matrix, the mineralization occurs as hydrothermal veins of calcite, hematite and parisite-(Ce), and most of the samples display REE concentrations in the range of 2,500 to 4,200 ppm.

The Fazenda Varela parisite-(Ce) shows an excess of $\mathrm{Ca}$ and a deficiency of REE relative to an ideal composition due to the growth of syntaxial synchysite. The REE pattern of Fazenda Varela parisite-(Ce) is similar to the Fazenda Varela ferrocarbonatite. This mineral was formed in an environment with low $\mathrm{F}$ activity and high $\mathrm{Ca}$ and $\mathrm{CO}_{3}$ activities from hydrothermal fluid rising, which interacted strongly with carbonatite, resulting in the preferential partitioning of LREE probably as chlorine complexes. The hydrothermal mineral crystallization may have occurred due to increase activity of $\mathrm{HCO}_{3}^{-}$by the dissolution of magmatic carbonate or by the $\mathrm{pH}$ increase due to the water supply from the quartz-feldspar host rock.

Acknowledgements- The authors thank Ida di Carlo (ISTO, Université d'Orléans/CNRS) for the electronic microprobe analyses and the CNPq for providing funds (485415/2012-7 and 306249/2009-0 projects) and the MSc scholarship of the first author, who participates of the "Programa de Pósgraduação em Geociências, UFRGS".

\section{References}

Anders, E. \& Grevesse, N. 1989. Abundances of the elements: Meteoritic and solar. Geochimica et Cosmochimica Acta, 53(1): 197-214.

Bayliss, P. \& Levinson, A.A. 1988. A system of nomenclature for rare-earth mineral species: Revision and extension. 
American Mineralogist, 73: 422-423.

Botelho, N.F. \& Teixeira, L.M. 1995. Caracterização química de minerais de terras raras e sua aplicação à petrologia dos granitos da província estanífera de Goiás. In: III CONGRESSO BRASILEIRO DE GEOQUÍMICA, 1995, Niterói. Resumos Expandidos. Niterói, RJ.

Caro, P.E. 1973. Structure lammellaires: syntaxie, polytypie et non-stoechiométrie. Journal of Solid State Chemistry, 6: 396-401.

Chakhmouradian, A.R. \& Wall, F. 2012. Rare earth elements: minerals, mines, magnets (and more). Elements, 8 (5): 333-340.

Chakhmouradian, A.R. \& Zaitsev, A.N. 2012. Rare earth mineralization in igneous rocks: Sources and processes. Elements, 8: 347-353.

Cordeiro, P.F.O., Brod, J.A., Palmieri, M., Oliveira, C.G., Barbosa, E.S.R., Santos, R.V., Gaspar, J.C. \& Assis, L.C. 2011. The Catalão I niobium deposit, Central Brazil: resources, geology and pyrochlore chemistry. Ore Geology Reviews, 41 (1): 112-121.

Dani, N. 1998. Petrologia das alterações pós-magmáticas e meteóricas das rochas alcalinas de Lages, SC - Brasil. Porto Alegre, 228p. Tese de doutorado, Programa de Pós-graduação em Geociências, Instituto de Geociências, Universidade Federal do Rio Grande do Sul, Brasil.

Deines, P. \& Gold, D.P. 1973. The isotopic composition of carbonatite and kimberlite carbonates and their bearing on isotopic composition of deep-seated carbon. Geochimica et Cosmochimica Acta, 37: 1707-1733.

Donnay, G. \& Donnay, J.D.H. 1953. The crystallography of bastnäsite, parasite, röntgenite and synchysite. American Mineralogist, 38: 932-963.

Förster, H.J. 2001. Synchysite-(Y) - synchysite-(Ce) solid solutions from Markersbach, Erzgebirge, Germany: REE and Th mobility during high-T alteration of highly fractionated aluminous A-type granites. Mineralogy and Petrology, 72: 259-280.

Kynicky, J., Smith, M.P. \& Xu, C. 2012. Diversity of rare earth deposits: the key example of China. Elements, 8: 361-367.

Lapido-Loureiro, F.E.V. 1994. Terras-Raras no Brasil: Depósitos, Recursos Identificados, Reservas. Ministério da Ciência e Tecnologia, Conselho Nacional de Desenvolvimento Científico e Tecnológico, Centro de Tecnologia Mineral, 21: $183 p$.

Lottermoser, B.G. 1990. Rare-earth element mineralization within the Mt. Weld carbonatite laterite, western Australia. Lithos, 24: 151-167.

Lottermoser, B.G. \& England, B.M. 1988. Compositional variation in pyrochlores from the Mt. Weld carbonatite laterite, Western Australia. Mineralogy and Petrology, 38: 37-51.

Mariano, A.N. 1989. Economic geology of rare earth minerals. Mineralogical Society of America Reviews in Mineralogy, 21: 308-338.

Mariano, A.N. \& Mariano Jr., A. 2012. Rare earth mining exploration in North America. Elements, 8: 369-376.

Menegotto, E. \& Formoso, M.L.L. 1998. Alteração Intempérica do Carbonatito da Fazenda Varela - Região de Lages, Santa Catarina, Brasil. Geochimica Brasiliensis, 12 (1/2): 093-112.

Meng, D., Wu, X., Yung, G., Pan, Z. \& Li, D. 1995. TEM study of the microstructure in calcium-rare-earth fluorcarbonate minerals. In: CHINA-JAPAN ELECTRON MICROSCOPY SEMINAR, 8, Proceedings..., p. 97-102.
Meng, D., Wu, X., Pan, Z. \& Yang, G. 1996. HRTEM study of CaRE fluorcarbonate mineral series. In: INTERNATIONAL GEOLOGICAL CONGRESS, 30, 1996, Abstracts...Beijing, v. 2, p. 499.

Meng, D., Wu, X., Pan, Z., Yang, G., Li, D. \& Hu, K. 1997. HRTEM study of three new regular mixed-layer structures in calcium-rare-earth fluorcarbonates minerals. Rare Earth Society, 15: 38-44.

Meng, D., Wu, X., Mou, T. \& Li, D. 2001a. Determination of six new polytypes in parisite-(Ce) by means of high resolution electron microscopy. Mineralogical Magazine, 65: 797-806.

Meng, D., Wu, X., Mou, T. \& Li, D. 2001b. Microstructural investigation of new polytypes of parisite-(Ce) by high-resolution transmission electron microscopy. The Canadian Mineralogist, 39: 1713-1724.

Metz, M.C., Brookins, D. G., Rosenberg, P.E. \& Zartman, R.E. 1985. Geology and geochemistry of the Snowbird deposit, Mineral County, Montana. Economic Geology, 80: 394409.

Ni, Y., Post, J.E. \& Hughes, J.M. 2000. The crystal structure of parasite-(Ce), $\mathrm{Ce}_{2} \mathrm{CaF}_{2}\left(\mathrm{CO}_{3}\right)_{3}$. American Mineralogist, 85: 251-258.

Pereira, R.M., Castro, C., Neumann, R. \& Ávila, C.A. 2008. Minerais de metais e elementos raros associados ao Granito Desemborque, São Paulo. Revista Brasileira de Geociências, 38 (4): 591-597.

Rocio, M.A.R., Silva, M.M., Carvalho, P.S.L. \& Cardoso, J.G.R. 2012. Terras-raras: situação atual e perspectivas. BNDS Setorial, 35: 369-420.

Ruberti, E., Enrich, G.E.R., Gomes, C.B. \& Comin-Chiaramonti. 2008. Hydrotermal REE fluorcarbonate mineralization at Barra do Itapirapuã, a multiple stockwork carbonatito, southern Brazil. The Canadian Mineralogist, 46: 901-914.

Savel'eva, V.B. \& Karmanov, N.S. 2008. REE minerals of alcaline metasomatic rocks in the Main Sayan Fault. Zapiski Rossiiskogo Mineralogicheskogo Obshchestva, 2: 14-36

Scheibe, L.F. 1979. Estudo petrológico e geoquímico dos carbonatitos da Fazenda Varela, SC. Porto Alegre, 120p., Dissertação de Mestrado, Programa de Pós-graduação em Geociências, Universidade Federal do Rio Grande do Sul.

Scheibe, L.F. 1986. Geologia e petrologia do distrito alcalino de Lages, SC. São Paulo, 224p., Tese de Doutorado, Instituto de Geociências, Universidade de São Paulo,

Scheibe, L.F. \& Formoso, M.L.L. 1982. Contribuição da geoquímica das terras raras à caracterização dos carbonatitos da Fazenda Varela, Lages, SC. Revista Brasileira de Geociências, 12 (4): 553-561.

Scheibe, L.F., Kawashita K. \& Gomes, C.B. 1985. Contribuição à geocronologia do Complexo Alcalino de Lages, SC. In: SIMPÓSIO SUL-BRASILEIRO DE GEOLOGIA, 2, 1985, Florianópolis, Anais..., Florianópolis, SBG (Núcleo RS, SC e PR), v.1, p.299-307.

Service, R.F. 2010. Nations move to head off shortages of rare earths. Science, 327 (5973): 1596-1597.

Stone, R. 2009. As China's rare earth R\&D becomes ever more rarefied, others tremble. Science, 325: 1336-1337.

Taylor, H.P., Frechen, J. \& Degens, E.T. 1967. Oxygen and carbon isotope studies of carbonatite from the Leacher See district, West Germany and the Alno district, Sweeden. Geochimica et Cosmochimica Acta, 31:407-430.

Van Landuyt, J. \& Amelincx, S. 1975. Multiple beam direct lattice imaging of new mixed-layers compounds os bastnaesite-synchysite series. American Mineralogist, 60: 351- 
358.

Wang, L., Ni, Y., Hughes, J.M., Bayliss, P. \& Drexler, J.W. 1994. The atomic arrangement of synchysite- $(\mathrm{Ce}), \mathrm{CeCaF}\left(\mathrm{CO}_{3}\right)_{2}$, Locality: Mont Saint-Hilaire, Quebec, Canada. The Canadian Mineralogist, 32: 865-871.

Williams-Jones, A.E., Migdisov, A.A. \& Samson, I.M. 2012. Hydrothermal mobilization of the rare earth elements - a tale of "ceria" and "yttria". Elements, 8: 355-360.

Woolley, A.R. \& Kempe, D.R.C. 1989. - Carbonatites: nomenclature, average chemical compositions, and element distribution. In: Bell, K. (Ed.). Carbonatites - Genesis and Evolution. London, Unwin Hyman, p. 1-14.

Wu, X., Meng, D., Pan, Z., Yang, G. \& Li, D. 1998a. Transmission electron microscopic study of new, regular, mixed-layer structures in calcium- rare-earth fluorcarbonate minerals. Mineralogical Magazine, 62: 55- 64.

Wu, X., Meng, D., Yang, G., Pan, Z., Li, D., Dai, J. \& Hu, K. 1998b. Syntactic intergrowth structure in the calcium-rare-earth fluorcarbonate minerals. Rare Earth Society, 16: 198-203.

Wu, X., Meng, D., Liang, J. \& Pan, Z. 1997. Ordered-disordered stacking structure along the c- /axis in calcium rare-earth fluorcarbonate minerals. In: INTERNATIONAL GEOLOGICAL CONGRESS, 30, 1997, Beijing. Anais... Beijing. IUGS, 16: 49-57.

Wu, X., Meng, D., Mou, T. \& Pan, Z. 2000. Domain structure in calcium-rare-earth fluorcarbonate minerals, Mianning County, Sichuan Province, China. Rare Earth Society, 18: 144-147.

Manuscrito 515.

Editores: Lauro Nardi \& Paulo A. Souza. 